\title{
Professional Rules for AtTORneys as a SubJeCt OF LEGAL EDUCATION IN GERMANY ${ }^{1}$
}

\author{
STEFAN KIRCHNER
}

\section{INTRODUCTION}

Approximately forty law schools across Germany's sixteen states prepare students for the First State Examination in Law, which opens the door to two years of practical training, the Referendariat, and subsequently the Second State Exam in Law, which also serves as the bar exam. While the Second State Exam (depending on the grade) also opens the door to other legal professions, the majority of graduates will enter the legal profession as an attorney (Rechtsanwalt ${ }^{2}$ ). Both the undergraduate education as well as the Referendariat combine theoretical and practical elements. While university students are usually required to complete three one-month long internships during the course of their studies, Rechtsreferendare usually spend four days a week at their workplace and one day a week in court-organized courses or practice exams in order to prepare for the Second State Examination in Law.

In recent years, the practical dimension has gained some importance for universities also, as laws at the state level require a greater practical approach in legal education than has been the case for a long time. Today, many law faculties offer courses in negotiation, legal rhetoric, foreign legal systems and law-related foreign language courses. Some law faculties have gone so far as to establish chairs or institutes dealing with questions of Anwaltsrecht (AR), that is, the set of legal rules pertaining to the profession

DOI: $10.1515 /$ wrlae-2015-0012

* University Lecturer for Fundamental and Human Rights, Faculty of Law, University of Lapland, Rovaniemi, Finland; admitted to the bar in Germany (Rechtsanwalt); Doctor in Social Sciences (Law), Vytautas Magnus University, Kaunas, Lithuania; Magister Juris Internationalis, Justus-Liebig-University, Giessen, Germany. Email: stefan.kirchner@ulapland.fi.

${ }^{1}$ The research for this article has been made possible by a grant by the Research Council of Lithuania (No. MIP-020/2012).

${ }^{2}$ Female form: Rechtsanwältin; plural: Rechtsanwälte (male), Rechtsanwältinnen (female). Since, unlike in the case of Anwaltsnotarinnen (female attorney-notaries), who still suffer some de jure discrimination, the same legal rules apply to male and female attorneys, the male form is used to increase the readability of this text. Unless stated otherwise, this is meant to refer to Rechtsanwältinnen, Rechtsreferendarinnen and other female lawyers as well. 
of Rechtsanwälte, in other words, the "law of lawyering". ${ }^{3}$ While there are some course offerings in AR at different German law faculties, the question needs to be asked whether German law, on the state or on the federal level, actually requires students to study Anwaltsrecht.

Substantive rules as to how to be admitted to the bar, how to be disbarred and how attorneys are expected/required to behave are contained in the Federal Lawyer's Act (Bundesrechtsanwaltsordnung, BRAO ${ }^{4}$ ) and the Rules of Conduct for Attorneys (Berufsordnung für Rechtsanwälte, BORA $^{5}$ ). The latter is not a law but a set of rules adopted by the elected representatives of attorneys. Another set of rules young lawyers should be made familiar with is the Attorneys' Fees Act (Rechtsanwaltsvergütungsgesetz, $\mathrm{RVG}^{6}$ ). In addition, during their time in law school students should develop at least a basic understanding of the German Judges' Act (Deutsches Richtergesetz, DRiG ${ }^{7}$ ), and the federal and state rules pertaining to public officials. Frequently, neither of these laws is strictly required by the curriculum. For the purposes of this text, a rather narrow definition of Anwaltsrecht will be used, referring to the substantive (rather than procedural) rules included in the BRAO. As most law graduates will become attorneys, they should enter the Referendariat with at least a basic understanding of the legal requirements for becoming an attorney and how attorneys are required by the law to conduct themselves.

The question of what the law actually requires students to study is becoming more important because there is a visible trend in German law schools of students demanding a more school-like learning experience rather than the academic freedom this author and earlier generations were able benefit from. As a consequence of a more streamlined education system and a more demanding job market, many law students focus on obligatory courses and refrain from any activity which is not required in order to graduate as quickly and effectively as possible. While this is detrimental to the academic culture in Germany, it also leads to the question of whether law graduates after the First or Second State Examination in Law should be legally required to possess at least a basic knowledge of

\footnotetext{
3 "The Law of Lawyering" is the title of the annually updated standard work on rules for legal practitioners in the United States: Geoffrey C. Hazard, W. William Hodes, The Law of Lawyering (3rd edn, Aspen Publishers2013).

${ }^{4}$ Bundesrechtsanwaltsordnung, 1 August 1959, Bundesgesetzblatt (Federal Gazette) 1959

III No. 303-8 < http://www.gesetze-im-internet.de/bundesrecht/brao/gesamt.pdf $>$ an official English translation (up to date as of 2011) is available at

$<$ http://www.brak.de/w/files/02 fuer anwaelte/berufsrecht/brao eng stand 612 2011.pdf $>$.

${ }^{5}$ Berufsordnung für Rechtsanwälte

$<$ http://www.brak.de/w/files/02 fuer anwaelte/berufsrecht/bora stand 0111 13.pdf $>$ for an English translation (up to date as of 2013) see

$<$ http://www.brak.de/w/files/02 fuer anwaelte/berufsrecht/bora-engl-stand-1-112013.pdf $>$.

${ }^{6}$ Rechtsanwaltsvergütungsgesetz, 5 May 2004, Bundesgesetzblatt (Federal Gazette) 2004 I

718, $788<$ http://www.gesetze-im-internet.de/bundesrecht/rvg/gesamt.pdf $>$.

${ }^{7}$ Deutsches Richtergesetz, 8 September 1961, reissued 19 April 1972, Bundesgesetzblatt

(Federal Gazette) 1972 I $713<$ http://www.gesetze-im-

internet.de/bundesrecht/drig/gesamt.pdf $>$ English translation (2009) at

$<$ http://www.gesetze-im-internet.de/englisch drig/german judiciary act.pdf $>$.
} 
Anwaltsrecht in the narrow sense of the term. In order to answer the question of what German law requires law schools to teach in respect of Anwaltsrecht, the relevant state and federal rules will be analyzed in this article.

\section{SUBSTANTIVE RULES ON LEGAL PROFESSIONS}

A distinction needs to be made between substantive rules, which govern the behavior of attorneys, and the rules which regulate training in those rules.

\section{The Federal Lawyers' Act (Bundesrechtsanwaltsordnung)}

While the Federal Lawyers' Act regulates sanctions for unethical behavior by attorneys, assuming that no other exceptions apply (e.g. for attorneys already admitted to the bar in another EU member state) and there are no prior events on record which would render admission to the bar inappropriate, all that is required in terms of AR training is that the applicant for admission to the bar must be qualified to serve as a judge anywhere in Germany.

\section{The German Judiciary Act (Deutsches Richtergesetz)}

It is therefore necessary to look at the requirements established in the aforementioned German Judiciary Act. This law requires that future judges have studied law, undergone the Referendariat and passed the First and Second State Exams anywhere in Germany ${ }^{8}$. The Act also provides an outline of the scope of university studies ${ }^{9}$ and of training during the Referendariat, ${ }^{10}$ respectively. The curriculum has to take into account, inter alia, the practice of legal consulting, "including the necessary key qualifications such as negotiation management, leading discussions, rhetoric, dispute resolution, mediation [...] and the ability to communicate." ${ }^{11}$ While this list is not exhaustive, ${ }^{12}$ the examples given - as well as the explicit reference to skills rather than knowledge - indicates that this provision is not meant to include knowledge of AR. The Judiciary Act rather indicates that there is an expectation that the practical training a Referendar receives while working in a law firm is appropriate in terms of legal consultation. ${ }^{13}$ While it cannot be excluded that a broad interpretation of the aforementioned rules ${ }^{14}$ to include education in AR might be desired, it would more than a stretch of the law's wording to interpret it in a way which would oblige Germany's federal states - which, under the German

\footnotetext{
${ }^{8} \S 5$ DRiG.

9 \$ 5 a DRiG.

$10 \S 5$ b DRiG.

${ }^{11} \S 5 \mathrm{a}(3)$ sentence $1 \mathrm{DRiG}$.

12 ibid.

${ }^{13} \S 5$ b (4) DRiG.

$14 \S 5 \mathrm{a}(3) \mathrm{s} .1$ and $\S 5 \mathrm{~b}(4) \mathrm{DRiG}$.
} 
constitution ${ }^{15}$ are in principle the primary authorities in regulating educational matters ${ }^{16}$ — to require law schools to offer courses in AR.

\section{STATE-LEVEL LAWS AND ORDINANCES ON LEGAL EDUCATION: JURISTENAUSBILDUNGSGESETZE AND -PRÜFUNGSORDNUNGEN}

\section{Federal and state level law-making competencies}

As the responsibility for law-making in educational matters rests with Germany's federal states, ${ }^{17}$ they have enacted state-level legislation concerning the training of lawyers. The prevailing way of doing so is with a more general law, usually referred to as the Law on the Education of Jurists (Juristenausbildungsgesetz, JAG), and a more detailed ordinance, usually called the Ordinance on the Education and Examination of Jurists (Juristenausbildungs- und -prüfungsordnung, JAPO) or something similar. Given that individuals having passed the Second State Examination are, in theory, permitted to work in all legal functions everywhere in Germany (e.g. as judges ${ }^{18}$ or attorneys ${ }^{19}$ ), and that passing the First State Examination opens the door to the Referendariat throughout all of Germany, it is hardly surprising that the laws of the different states are quite similar. In the following, the more specific ordinances will be examined as they outline in detail which subjects students must study for the First and the Second State Examinations. While there are some differences between the states with regard to the detailed selection of the laws of which a basic or a more advanced knowledge is required, the broader national legal job market would lead one to assume that requirements concerning the study of Anwaltsrecht should be more or less similar across jurisdictions, varying only in details. This is not the case. While it is common that courses are offered introducing Referendare to the work of attorneys (so-called Anwaltslehrgänge ${ }^{20}$ ), this does not necessarily translate to AR being an obligatory subject in the Second State Examination in Law, let alone in the First.

\section{Different state-level requirements}

\footnotetext{
${ }^{15}$ Grundgesetz (Basic Law), Bundesgesetzblatt (Federal Gazette) 1949, 1 $<$ http://www.gesetze-im-internet.de/bundesrecht/gg/gesamt.pdf $>$ English translation (2012) at $<$ http://www.gesetze-iminternet.de/englisch gg/basic law for the federal republic of germany.pdf $>$. ${ }^{16}$ Art. 70 (1) GG.

17 ibid.

${ }^{18}$ Cf. $\S 5$ (1) DRiG.

${ }^{19} \S 5$ BRAO.

${ }^{20}$ See e.g. $\S 25$ of the Ordinance on the Implementation of the Law concerning the Education of Lawyers, Hesse (Verordnung zur Ausführung des Juristenausbildungsgesetzes, Hessen, HessJAO), 25 October 2004, Gesetz- und Verordnungsblatt, Hessen (HessGVB1.) (Hesse Gazette) 2004, 316, last amended on 24 May 2011, HessGVB1. 2011, 206. This ordinance is based on $\S 57$ (1) of the Law on the Legal Education, Hesse (Juristenausbildungsgesetz, Lessen, HessJAG), 15 March 2004, HessGVB1. 2004, 158, last amended on 27 May 2013, HessGVB1. 2013, 218.
} 
The different requirements for legal education across Germany's sixteen states range from no requirement to study AR at all to an obligation to do so.

\subsection{Obligatory AR training}

The state of Baden-Württemberg requires some knowledge of AR to pass the first State Examination in Law: According to $\S 51$ (1) No. 11 of the Ordinance of the Ministry of Justice concerning the Education and Examination of Jurists (Verordnung des Justizministeriums über die Ausbildung und Prüfung der Juristen ${ }^{21}$ ), commonly referred to as the Jurists Education and Examination Ordinance (Juristenausbildungs- und Prüfungsordnung, BaWüJAPrO), obligatory exams can include legal issues under the Bundesrechtsanwaltsordnung as well as concerning the Berufsordnung für Rechtsanwälte as far as fundamental rules, admission to the bar, the supervision of attorneys and rules on professional conduct are concerned. In addition, students are required to have knowledge about the mandate as a legal institution, including liability issues and the "Anwaltspraxis" 22 (literally "Attorney Practice") in the other obligatory subjects. How the latter can be learned prior to admission to the bar is unclear. Presumably, the justice ministry expects students to have an understanding of practical issues rather than practical experience. AR can additionally be chosen as a Schwerpunktbereich (an obligatory elective area of specialization) during the Referendariat. In this case, during the final, the oral exam which constitutes part of the Second State Examination in Law includes not only the subjects mentioned in $\S 51$ (1) No. 11 BaWüJAPrO but also legal rules concerning attorneys' fees, different (presumably corporate law) forms of cooperation between attorneys, dispute resolution as well as the establishment, operation and organization of a law firm. ${ }^{23}$

\subsection{AR as an elective subject}

In Bavaria (Bayern), Referendare who have chosen the obligatory elective field "Anwaltschaft" ("attorneyship") are required by $\S 58$ (3) No. 3 of the Education and Examination Ordinance for Jurists (Ausbildungs- und Prüfungsordnung für Juristen, ${ }^{24}$ BayJAPO) to study the legal rules relating to the exercise of the profession of attorney, ${ }^{25}$ attorney marketing law, ${ }^{26}$ attorney fees law, ${ }^{27}$ tactics and private and criminal law liability of attorneys, ${ }^{28}$ preventive legal consultation from the perspective of

\footnotetext{
${ }^{21}$ Ordinance of the Ministry of Justice concerning the Education and Examination of Jurists (Verordnung des Justizministeriums über die Ausbildung und Prüfung der Juristen, BaWüJaPrO), 8 October 2002, Baden-Württemberg Gazette (Gesetzblatt BadenWürttemberg, BW GB1.) 2002, 391.

${ }^{22} \S 51$ (1) no. 11 BaWüJaPrO.

${ }^{23} \S 51$ (2) No. 2 BwWüJAPrO.

24 Education and Examination Ordinance for Lawyers, Bavaria (Ausbildungs- und Prüfungsordnung für Juristen, Bayern, BayJAPO), 13 October 2003, Bavarian Gazette (Gesetz- und Verordnungblatt, GVB1. 2003, 758).

${ }^{25} \S 58$ (3) No. 3 (lit. a) BayJAPO.

${ }^{26}$ ibid.

27 ibid., lit. b).

28 ibid., lit. c).
} 
attorneys,${ }^{29}$ and fundamentals of mediation. ${ }^{30}$ In addition, candidates for the Second State Examination in Law in Bavaria who have chosen this track have to acquire in-depth knowledge of obligatory subject areas from the perspective of attorneys, ${ }^{31}$ that is, taxation of the work of attorneys, ${ }^{32}$ claims enforcement from the attorney's perspective ${ }^{33}$ and interim relief. ${ }^{34}$

Under $\S 27$ (3) No. 1 of Berlin's Lawyer Education Ordinance ${ }^{35}$ as well as under $\S 46$ (3) No. 3 lit. a) of the counterpart legislation in the state of Thuringia, ${ }^{36} \mathrm{AR}$ is one of the possible fields of law covered by an obligatory elective subject (meaning that candidates must choose a field in which to be examined) exam in the context of the Second State Examination in Law.

\subsection{No requirement to study $A R$}

While exams in other fields of law, such as criminal or business law, can be written from the perspective of an attorney ${ }^{37}$ (which does not include $\mathrm{AR}$ issues), the vast majority of states (Brandenburg, ${ }^{38}$ Bremen, ${ }^{39}$

\footnotetext{
${ }^{29}$ ibid., lit. d)

${ }^{30}$ ibid., lit. e).

31 ibid., lit. f).

32 ibid.

33 ibid.

34 ibid.
}

${ }^{35}$ Education and Examination Ordinance for Jurists in the State of Berlin (Ausbildungsund Prüfungsordnung für Juristinnen und Juristen im Land Berlin, Berliner Juristenausbildungsordnung, BerlinJAO), 4 August 2003, Berlin Gazette (Gesetz- und Verordnungsblatt, Berlin, BerlinGVB1.) 2003, 298, last amended on 20 September 2010, BerlinGVB1. 2010, 470. This ordinance is based on $\S 24$ of the Law on the Education of Jurists in the State of Berlin (Gesetz über die Ausbildung von Juristinnen und Juristen im Land Berlin, Berliner Juristenausbildungsgesetz, BerlinJAG), 23 June 2003, BerlinGVB1. 2003, 232, last amended on 19 March 2009, BerlinGVB1. 2003, 70.

${ }^{36}$ Thuringian Jurist Education and Examination Ordinance (Thüringer Juristenausbildungsund -prüfungsordnung, ThürJAPO), 24 February 2004, Thüringia Gazette (Gesetz- und Verordnungsblatt, Thüringen, ThürGVB1.) 2004, 217, last amended on 20 March 2009 (ThürGVBl. 2009, 238). This ordinance is based on $\S 8$ of the Thuringian Law on the State Examinations in Law and the Legal Preparatory Service (Thüringer Gesetz über die juristischen Staatsprüfungen und den juristischen Vorbereitungsdienst, Thüringer Juristenausbildungsgesetz, ThürJAG), 28 January 2003, ThürGVB1. 2003, 33, last amended on 20 March 2009, ThürGVB1. 2009, 238.

${ }^{37}$ See for example $\S 37$ (4) of the Legal Education and Examination Ordinance of the State of Rhineland-Palatinate (Juristische Ausbildungs- und Prüfungsordnung, Rheinland-Pfalz, RhPfJAPO), 1 July 2003, Rhineland-Palatinate Gazette (Gesetz- und Verordnungsblatt Rheinland-Pfalz, RhPfGVB1.) 2003, 131, last amended on 23 July 2010, RhPfGVB1. 2010, 249. This ordinance is based on $\S 6$ (3) sentence 1 and $\S 9$ (1) of the State Law on Legal Education (Landesgesetz über die juristische Ausbildung), 23 June 2003, RhPfGVB1. 2003, 116.

38 Education and Examination Ordinance for Jurists in the State of Brandenburg (Ausbildungs- und Prüfungsordnung für Juristen im Land Brandenburg, Brandenburgische Juristenausbildungsordnung, BbgJAO), 6 August 2003, Brandenburg Gazette (Gesetz- und Verordnungsblatt, BbgGVB1. 2003, II/03 [No. 20], 438), last amended on 22 November 2010 (BbgGVB1. 2010, II/10 [No. 80]). This ordinance is based on $\S 24$ (1) No. 1 and 2 lit. a) - c) and $\S 24$ (1) No. 3-5 of the Law on the Education of Jurists in the State of Brandenburg (Gesetz über die Juristenausbildung im Land Brandenburg, Brandenburgisches Juristenausbildungsgesetz, BbgJAG), 24 June 2003, BbgGVB1. 2003, I/03 [No. 09], 166, last amended on 20 November 2013, BbgGVB1. 2013, I/13 [No. 32].

${ }^{39}$ For the First State Examination in Law see the Bremian Law on the Education of Jurists and the First State Exmaination in Law (Bremisches Gesetz über die Juristenausbildung 
Hamburg, ${ }^{40}$ Hesse, ${ }^{41}$ Mecklenburg-Western Pomerania, ${ }_{42}^{42}$ Northrhine-

und die erste juristische Staatsprüfung, Juristenausbildungs- und -prüfungsgesetz, BremJAPG), 20 May 2003, Bremen Gazette (Bremisches Gesetzblatt, Brem.GB1.) 2003, 251. The Second State Examination in Law in the states of Hamburg, Bremen and Schleswig-Holstein is organised under an inter-state agreement between the three states: Übereinkunft der Länder Freie Hansestadt Bremen, Freie und Hansestadt Hamburg und Schleswig-Holstein über ein Gemeinsames Prüfungsamt und die Prüfungsordnung für die zweit Staatsprüfung für Juristen, last amended on 20 April 2005, available online at $<$ http://justiz.hamburg.de/contentblob/1494186/data/neuelaenderuebereinkunft-2005.pdf $>$ accessed 6 June 2014.

${ }^{40}$ For the First State Examination in Law see the Hamburg Law on the Education of Jurists (Hamburgisches Juristenausbildungsgesetz, HmbJAG), 11 June 2003, Hamburg Gazette (Hamburgisches Gesetz- und Verordnungsblatt, HmbGVB1.) 2003, 156, last amended on 27 December 2007, HmbGVB1. 2008, 26. The Second State Examination in Law in the states of Hamburg, Bremen and Schleswig-Holstein is organised under an inter-state agreement between the three states: Übereinkunft der Länder Freie Hansestadt Bremen, Freie und Hansestadt Hamburg und Schleswig-Holstein über ein Gemeinsames Prüfungsamt und die Prüfungsordnung für die zweit Staatsprüfung für Juristen, last amended on 20 April 2005, available online at $<$ http://justiz.hamburg.de/contentblob/1494186/data/neuelaenderuebereinkunft-2005.pdf $>$ accessed 6 June 2014.

${ }^{41}$ Ordinance on the Implementation of the Law concerning the Education of Lawyers, Hesse (Verordnung zur Ausführung des Juristenausbildungsgesetzes, Hessen, HessJAO), 25 October 2004, Hesse Gazette (Gesetz- und Verordnungsblatt, Hessen, HessGVB1.) 2004, 316, last amended on 24 May 2011, HessGVB1. 2011, 206. This ordinance is based on $\S 57$ (1) of the Law on the Legal Education, Hesse (Juristenausbildungsgesetz, Hessen, HessJAG), 15 March 2004, HessGVB1. 2004, 158, last amended on 27 May 2013, HessGVB1. 2013, 218.

42 Ordinance to implement the Law on the Education of Jurists (Verordnung zur Durchführung des Juristenausbildungsgesetzes, Juristenausbildungs- und prüfungsordnung, JAPO M-V), 16 June 2004, Mecklenburg-Western Pommerania Gazette (Gesetz- und Verordnungsblatt Mecklenburg-Vorpommern, GVOB1. M-V) 2004, 281. This ordinance is based on $\S 28$ (1) of that state's Lawyers' Education Law (Juristenausbildungsgesetz, JAG M-V), 16 December 1992, GVOB1. M-V 1992, 725, last amended on 21 June 2004, GVOB1. M-V 2004, 278.

${ }^{43}$ Ordinance on the Implementation of the Law on the State Examinations in Law and the Legal Preparatory Service in Northrhine-Westphalia (Verordnung über die Durchführung des Gesetzes über die juristischen Staatsprüfungen und den juristischen Vorbereitungsdienst in Nordrhein-Westfalen, Juristenausbildungsordnung, NRWJAO), 8 November 1993,Northrhine-Westphalia Gazette, GVB1. NW) 1993, 932, last amended on 25 August 1994, GVB1. NW 1994, 702. This ordinance is based on $\S 65$ (2) of the Law on the Legal Examinations and the Legal Preparatory Service (Gesetz über die juristischen Prüfungen und den juristischen Vorbereitungsdienst, Juristenausbildungsgesetz NordrheinWestfalen, JAG NRW), 11 March 2003, GVB1. NW 2003, 135, correction GVB1. NW 2003, 431, last amended on 4 February 2014, GVB1. NW 2014, 104.

${ }^{44}$ Verordnung zum Niedersächsischen Gesetz zur Ausbildung der Juristinnen und Juristen, 2 November 1993, Lower Saxony Gazette (Niedersächsisches Gesetz- und Verordnungsblatt, NdsGVB1.) 1993, 561, last amended on 11 September 2009, NdsGVB1. 2009, 348. This ordinance is based on the Niedersächsisches Gesetz zur Ausbildung der Juristinnen und Juristen, 15 January 2004, NdsGVB1. 2004, 7, last amended on 25 March 2009, NdsGVB1. 2009, 72.

${ }^{45}$ Legal Education and Examination Ordinance of the State of Rhineland-Palatinate (Juristische Ausbildungs- und Prüfungsordnung, Rheinland-Pfalz, RhPfJAPO), 1 July 2003, Rhineland-Palatinate Gazette (Gesetz- und Verordnungsblatt Rheinland-Pfalz, RhPfGVB1.) 2003, 131, last amended on 23 July 2010, RhPfGVB1. 2010, 249. This 
Saxony, ${ }^{47}$ Saxony-Anhalt ${ }^{48}$ and Schleswig-Holstein ${ }^{49}$ ) do not refer to AR in their education and examination ordinances. In those states it is up to students (and later Referendar) to obtain knowledge of AR on their own. The ability to acquire knowledge on one's own is a key characteristic which distinguishes a university student from a pupil in school. Unfortunately, there is currently a trend to the effect that many university students approach university not so much from the perspective of academic freedom, but from the perspective of a consumer. In doing so they transfer their previous learning experience from school and enter university with the expectation that the task of a university professor is the same as that of a school teacher. This is not the case. It certainly is possible to transfer knowledge about legal issues in a way which would resemble teaching in school. This would, however, miss the point of not only university, but also of what is expected from graduates. Attorneys (and public officials and judges as well) have to be able to deal with novel situations. The law itself will often be insufficient to answer all questions easily. Studying law is more than learning the contents of codes or memorizing case law. What is required is an understanding of the law and the ability to solve legal

ordinance is based on $\S 6$ (3) sentence 1 and $\S 9$ (1) of the Landesgesetz über die juristische Ausbildung (State Law on Legal Education), 23 June 2003, RhPfGVB1. 2003, 116.

${ }^{46}$ Ordinance on the Implementation of the Law concerning Legal Education (Verordnung zur Ausführung des Gesetzes über die juristische Ausbildung, Juristenausbildungsordnung, SaarJAO), 3 October 1988, Saarland Gazette (Amtsblatt Saarland, SaarAB1.) as promulgated on 8 January 2004, SaarAB1. 2004, 90, last amended on 20 October 2011, SaarAB1. 2011, 352. This ordinance is based on $\S 36$ (1) of the Law concerning Legal Education (Gesetz über die juristische Ausbildung, Juristenausbildungsgesetz, SaarJAG), of 6 July 1988, SaarAB1. 1988, 865, last amended on 8 July 1998, SaarAB1. 1998, 718.

47 Education and Examination Ordinance for Jurists of the Free State of Saxony (Ausbildungs- und Prüfungsordnung für Juristen des Freistaates Sachsen, SächsJAPO), 7 April 2006, Saxonian Gazette (Sächsisches Gesetz- und Verordnungsblatt, SächsGVB1.) 2006, 305, last amended on 9 July 2013, SächsGVB1. 2013, 560. This ordinance is based on $\S 8$ of the Law on the Education of Jurists in the Free State of Saxony (Gesetz über die Juristenausbildung im Freistaat Sachsen, SächsJAG), 27 June 1991, SächsGVB1. 1991, 224, last amended on 18 December 2013, SächsGVB1. 2013, 970.

${ }^{48}$ Education and Examination Ordinance for Jurists, Saxony-Anhalt (Ausbildungs- und Prüfungsordnung für Juristen, Sachsen-Anhalt, Sachs-AnhJAPrVO), 2 October 2003, Gazette of the State of Saxony-Anhalt (Gesetz- und Verordnungsblatt des Landes SachsenAnhalt, Sachs-AnhGVB1.) 2003, 245, corrected text 2003, 349, last amended on 15 December 2009, Sachs-AnhGVB1. 2009, 648. This ordinance is baed on $\S 9$ (1) of the Law on the Education of Jurists in the State of Saxony-Anhalt (Juristenausbildungsgesetz, Sachsen-Anhalt, JAG LSA), 16 July 2003, Sachs-AnhGVB1. 2003, 167.

${ }^{49}$ For the First State Examination in Law see the State Ordinance on the Education of Jurists (Landesverordnung über die Ausbildung der Juristinnen und Juristen, SchleswigHolstein, SHJAVO), 15 February 2014, Schleswig-Holstein Gazette (Gesetz- und Verordnungsblatt Schleswig-Holstein, SHGVOB1.) 2014, 35. This ordinance is based on $\S$ 14 of the Lawyers' Education Law (Juristenausbildungsgesetz, SHJAG), 20 February 2009, SHGVOB1. 2009, 66, last amended on 26 March 2009, SHGVOB1. 2009, 93. The Second State Examination in Law in the states of Hamburg, Bremen and Schleswig-Holstein is organised under an inter-state agreement between the three states: Übereinkunft der Länder Freie Hansestadt Bremen, Freie und Hansestadt Hamburg und Schleswig-Holstein über ein Gemeinsames Prüfungsamt und die Prüfungsordnung für die zweite Staatsprüfung für Juristen, last amended on 20 April 2005, available online at $<$ http://justiz.hamburg.de/contentblob/1494186/data/neuelaenderuebereinkunft-2005.pdf $>$ accessed 6 June 2014. 
problems. It must be kept in mind that upon passing the Second State Examination in Law, a graduate (then referred to as an Assessor or Assessorin) is in theory (in practice depending on the grades) qualified to become a judge. Many cases in the first instance are decided by individual judges, and at times there are only a few months between the end of the Referendariat and the commencement of work as a judge. If one assumes that a student enters university at age 17 or 18 (as opposed to age 19 or 20, as was the case a few years ago before many states reduced schooling from 13 to 12 years and the draft to the armed forces was abolished), and that the student is able to concentrate on studies, does not need to work, and can cover the material very quickly (e.g. in three years), followed immediately (in practice usually a few months later, due to the paperwork involved) by two years of Referendariat, it is no longer inconceivable to have judges who are only aged 23 . While these young lawyers might be legally qualified to work as judges, the question must be asked if a minimum amount of life experience outside school, university and Referendariat should be required for such a responsible position. The law at present does not require this, indeed, in $\S 7$ (1) of the Hesse State Law on Public Officials (Hessisches Beamtengeset $^{50}$ ) we can see, for example, that life experience is seen as an alternative to professional qualifications, not as a requirement which would be additional to such qualifications.

\section{SHOULD STUDENTS BE LEGALLY OBLIGED TO STUDY AR?}

It should therefore be noted that despite the fact that the vast majority of law students will one day work as attorneys (Rechtsanwälte), most are not obliged to study the rules which pertain to their future profession. While they are expected to be familiar with these rules upon being admitted to the bar, this responsibility is left to the future lawyers themselves.

Nevertheless, if university education is not only about knowledge but also about skills, and taking into account that not all law graduates will work as attorneys, the question must be asked if the study of AR should be obligatory. One could argue that only a small fraction of all graduates will work in constitutional law, but the necessity to teach constitutional law would hardly be questioned. This argument, though, could almost be continued ad infinitum. German legal studies are already very long, which is a consequence of the idea that somebody who has passed the Second State Examination in Law will be able to work in many different legal functions and in many different legal subject areas. Nevertheless, the last sentences of the preceding paragraph open the door to the argument that it is not necessary for lawyers to have been trained in AR.

German lawmakers at the state level overall appear to aim at orienting the education of young lawyers at the university level towards practice. In the Referendariat, practical work is complemented by

\footnotetext{
${ }^{50}$ Hessian Law on Public Officials (Hessisches Beamtengesetz, HBG), 21 March 1962, HessGVB1. 1962, 173.
} 
obligatory courses. While it cannot be excluded that AR issues play a role during the time spent working at a law firm, there is no obligation to engage in them, and it is rather unlikely as the focus will be on the skills and knowledge which are necessary to pass the Second State Examination in Law. Only some of Germany's sixteen federal states require any knowledge of AR to pass either the First or the Second State Examination in Law.

The choice not to include AR in the obligatory part of the curriculum and in the required knowledge for the State Examinations in Law reflects the traditional view which underlies the education of lawyers in Germany. The Referendar is trained to assist a judge, and the Assessor is trained to become a judge. While the reality on the ground is different in that the vast majority of graduates will work as attorneys, this is only partially reflected in the state laws on legal education. This becomes clear when considering, for example, that Criminal Procedure Law is an obligatory part of the Second State Exam, even for lawyers who already know that they will never work in criminal law, while AR does not play a role.

Including AR in the required curriculum would also be inconsistent with the systematic approach followed by states' laws on legal education. These state rules refer to academic categories - criminal law, administrative law and so on. Very often, courses in Germany are designed along these dogmatic lines, and in the first years of legal education this approach is essential to provide students with a sound basic legal education. What the German system of legal education could use more of (and what already exists in the form of elective courses) are topic-oriented courses, such as law concerning the elderly, medical law etc. These issues transcend classical dogmatic categories. Medical law can deal with public health insurance law, private law contracts between physician and patient, criminal responsibility or tort law liability for medical malpractice. AR is treated similarly.

While there have been some improvements concerning the practical dimension of university legal education in recent years, and despite the fact that more faculties are offering courses in Anwaltsrecht, the choice to attend these courses is still one which relies heavily on the interest of students. This has the benefit that employers can, at least to some extent, draw conclusions concerning the interest of graduates in AR issues from their choice of courses during their university studies. On the downside, there is no guarantee that new attorneys are actually familiar with the legal rules which govern their chosen profession. The basic idea of the profession of Rechtsanwalt is one which is very much based on notions of freedom and responsibility. Therefore, there seems to be a legally relevant expectation of the lawmaker that attorneys live up to their responsibilities by actually becoming (and staying) informed about AR. As long as attorneys are aware of this responsibility and fulfill it, the system works. It can be expected of attorneys to known the legal rules pertaining to their own profession. Law schools have a moral responsibility to provide lawyers with the skills to obtain this information, but usually not a legal responsibility to provide such information. Law schools which aim at avoiding a disconnect between academia and legal practice would be well advised to go beyond what is required of them by state laws in order to offer future attorneys the chance to gain the skills and knowledge they will need in their future practice. Offering AR courses as electives is not only sufficient, but it is the most 
effective way to do so because not all students will become attorneys. AR courses could go beyond BRAO and BORA, including labour law rules (to be able to hire employees), how to make sure that your client actually pays, responsibility in cases of cooperation with foreign attorneys, etc. Understood in this manner, which would include legal ethics in a broader sense of the term, AR education offered by a law faculty could provide a given faculty with a distinct (if not necessarily unique) profile which would it turn make it an attractive destination for (future) law students who already know that they want to work as attorneys.

\section{Conclusions}

We can therefore conclude that German law does not require all future attorneys to have studied AR. While this is the case in some states, elsewhere future attorneys are expected to know the rules which apply to them. The changing academic landscape allows law faculties to offer a range of $\mathrm{AR}$ and $\mathrm{AR}$-related courses, thus improving the chance of law students to learn about their future profession as attorneys already at the undergraduate level. The current system does not mean that an attorney who studied in a state which did not require any knowledge in AR for the State Examinations is less qualified or more likely to run afoul of AR rules. They are, however, likely to have a head start when it comes to e.g. starting their own law firm, as many law graduates are forced to do if their grades are not sufficient to secure employment in an established firm. While states may rely on the responsibility of future attorneys to acquire the necessary knowledge, state-level lawmakers do law students and Referendare in their state no favours if they do not require them to study at least the most fundamental rules of $\mathrm{AR}$ at some point prior to the Second State Examination in Law.

Attorneys are meant to guarantee access to justice. However, lawyers are often more likely to be seen as bending the law rather than providing access to it. This public image is often inaccurate - but sometimes it is true. Therefore, the legal profession places a significant emphasis on the legal and ethical rules which govern the behavior of lawyers. This is particularly the case in Germany. The parts which form the composite word "Rechtsanwalt", the German word for attorney, are "Recht" (law or right) and "Anwalt", advocate. The letter "s" is more than merely a connecting element between the words, but also a genitive form. In the German word for patent lawyer, "Patentanwalt", this "s" is missing. The letter can be found in many composite words consisting of two true nouns (as opposed to composite words such as "Rechtmäßigkeit" or "Rechtswidrigkeit", the second half of which is based on words usually employed as adjectives) which begin with "Recht", such as "Rechtsreferendar" or "Rechtsstreit". The thing or person which is thus connected to the law is then one which is "of" the law. This is particularly true in the case of the Rechtsanwalt, who is understood to work not merely in the service of the client or the law firm, but in the service of law itself. This leads to a certain standard regarding what is expected of an attorney in Germany. Developments in recent years are changing these expectations, but the law is still very much fixated on the 
idea of lawyers working in offices with set opening hours. The reality on the ground for many lawyers looks very different, including in particular the nearly universal accessibility of case-related information. While an attorney should not handle case-related materials in public spaces such as airports, many lawyers and clients will question the integrity of their data security in a time when new reports emerge almost daily about the capabilities of governments to spy on everybody. In particular, for lawyers handling public law cases in which a client sues the government, this might raise the question of at which point a government will use such capacities not only to fight crime or terrorism, but also to win a lawsuit. Modern technological developments have another aspect as well: it is common today for information to be available at our fingertips practically everywhere, the majority of which is free of charge. This near ubiquity of free or cheap legal information leads to a whole range of challenges as lawyers are not needed for the same tasks today that they were in the past when legal texts were only available in thick and expensive bound books. In such an environment, skills matter at least as much as knowledge. Legal knowledge is no longer the monopoly of lawyers, but legal skills can help lawyers define specific services. Today's law students are faced with a rapidly-changing environment and with the problem that the law will often lag behind the latest technological and other developments. Lawmakers will also be affected by Amara's law, according to which "[w]e tend to overestimate the effect of a technology in the short run and underestimate the effect in the long run". ${ }^{51}$ In a way, we now face both "known [and] unknown unknowns", 52 as well as "unknown knowns". ${ }^{53}$ Both future developments and the impact of recent developments might be overlooked by lawmakers. This is not a new phenomenon, but for the current generation of law students it is likely to become a permanent condition. For attorneys in Germany, one example is the fact that, unless a rare exemption is granted, attorneys are required to have a physical office (it may even be in their living room, assuming that local zoning laws allow for the use of the building for such purposes). IT-enhanced mobility still poses serious questions to German lawyers. ${ }^{54}$ At the same time, technological developments also provide legal challenges in terms of substantative law in many other fields. Today, lawyers might ask themselves, for example, how secure their data is, in particular if they (as do most companies without IT departments) rely on the services of external contractors. The challenges lawyers will have to deal with tomorrow are often unimagineable today. In such circumstances, having a clear idea of what one's profession is about -

\footnotetext{
${ }^{51}$ Roy Amara, Amara's Law PC Mag Encyclopedia

$<$ http://www.pcmag.com/encyclopedia/term/37701/amara-s-law $>$ accessed 25 August 2014.

${ }^{52}$ Donald Rumsfeld, cited by Mark Steyn `Rummy speaks the truth, not gobbledygook`The Telegraph (9 December 2003)<http://www.telegraph.co.uk/comment/personalview/3599959/Rummy-speaks-the-truth-not-gobbledygook.html $>$ accessed 11 September 2015.

${ }^{53}$ Slavoj Zizek, 'What Rumsfeld Doesn't Know That He Knows About Abu Ghraib '(21 May 2004) <http://www.lacan.com/zizekrumsfeld.htm> accessed 11 September 2015. ${ }^{54} \S 27$ (1) BRAO requires a Rechtsanwalt or Rechtsanwältin to have a physical office, unless a exceptional permission is issued by the Rechtsanwaltskammer under $\S 29$ BRAO.
} 
an idea which is also an ideal and which can provide guidance through stormy legal and political seas - is an asset which should not be underestimated. Positivism and blind obedience of the written 'law' have led Germany to the worst crimes and the darkest hours of the nation's history. Many lawyers played a significant role in the National Socialist regime, while other attorneys suffered from injustices. After World War II, attorneys played key roles in the undemocratic government of East Germany. Many of the rules and structures of the legal profession in Germany, however, predate both regimes and often date back to the establishment of the Second German Empire in 1871. In a sense, German attorneys work in a broken continuum, and the legal profession in Germany is best characterized by two aspects: the freedom of the profession, and the responsibility which has led to a clear regulation of that profession. 